\title{
DIRECT PEDICLE SCREW INSERTION PULLOUT STRENGTH
}

\section{RESISTÊNCIA AO ARRANCAMENTO DO PARAFUSO PEDICULAR DE INSERÇÃO DIRETA}

\author{
Rômulo Pedroza Pinheiro ${ }^{1}$ (i), Ariane Zamarioli ${ }^{1}$ (i), Thibault Chandanson ${ }^{2}$ (i), Kerl George ${ }^{3}$ (1), \\ antonio Carlos Shimano ${ }^{1}$ (D), Helton Luiz ApareCido Defino ${ }^{1}$ (1) \\ 1. Universidade de São Paulo, Faculdade de Medicina de Ribeirão Preto, Departamento de Ortopedia e Anestesiologia, Ribeirão Preto, SP, Brazil. \\ 2. Université de Technologie de Belfort, Paris, France. \\ 3. University of Calgary, Alberta, Canada.
}

\section{ABSTRACT}

Objective: Study the in vitro pullout strength of SpineGuard/Zavation Dynamic Surgical Guidance Z-Direct Screw (DSG Screw), a screw pedicle designed to be inserted using a direct insertion technique. Methods: DSG Screws of $5.5 \mathrm{~mm}$ and $6.5 \mathrm{~mm}$ were introduced into polyurethane blocks with a density of $10 \mathrm{PCF}$ $\left(0,16 \mathrm{~g} / \mathrm{cm}^{3}\right)$. According to the experimental group, screws were inserted without pilot hole, with pilot without tapping, undertapping and line-to-line tapping. Screw pullout tests were performed using a universal test machine after screw insertion into polyurethane blocks. Results: Screws inserted directly into the polyurethane blocks without pilot hole and tapping showed a statistically higher pullout strength. Insertion of the screw without tapping or with undertapping increases the pullout screw strength compared to line-to-line tapping. Conclusion: DSG Screw showed the highest pullout strength after its insertion without pilot hole and tapping. Level of Evidence V, Expert Opinion.

Keywords: Pedicle Screws. Spinal Fusion. In Vitro Techniques. Tensile Strength.

\section{RESUMO}

Objetivo: Estudar a resistência ao arrancamento in vitro do parafuso de inserção direta da SpineGuard/Zavation (parafuso DSG), um parafuso pedicular projetado para ser inserido usando a técnica de inserção direta. Métodos: Parafusos DSG de 5,5 mm e 6,5 mm foram introduzidos em blocos de poliuretano com densidade de 10 PCF $(0,16 \mathrm{~g} / \mathrm{cm} 3)$. De acordo com o grupo experimental, os parafusos foram inseridos sem orifício piloto, com orifício e sem macheamento e macheamento diâmetro inferior com mesma geometria. Os testes de resistência dos parafusos foram realizados usando uma máquina de teste universal após a inserção dos parafusos nos blocos de poliuretano. Resultados: Os parafusos inseridos diretamente nos blocos de poliuretano sem orifício piloto e sem macheamento apresentaram uma resistência de arrancamento com significância estatística maior. A inserção do parafuso sem macheamento ou com macheamento com diâmetro inferior apresenta maior resistência ao arrancamento em comparação com o macheamento do mesmo diâmetro. Conclusão: O parafuso DSG apresentou a maior resistência ao arrancamento após sua inserção sem orifício piloto e sem macheamento. Nível de Evidência V, Opinião do Especialista.

Descritores: Parafusos Pediculares. Fusão Vertebral. Técnicas In Vitro. Resistência à Tração.

Citation: Pinheiro RP, Zamarioli A, Chandanson T, George K, Shimano AC, Defino HLA. Direct pedicle screw insertion pullout strength. Acta Ortop Bras. [online]. 2021;29(4):203-206. Available from URL: http://www.scielo.br/aob.

\section{INTRODUCTION}

The pedicle of lumbar and thoracic spine has been extensively used as implant anchorage in the spinal surgery. The biomechanical advantages of pedicle screw-based system and the clinical usefulness is supported by the reports of high rate of fusion, deformity correction and clinical outcomes. ${ }^{1}$

The use of pedicle screw is related to two topics that still are a challenge in the field of spinal surgery: accuracy of pedicle screw and exposure of surgeon to radiation. ${ }^{2}$

To improve accuracy and reduce radiation exposure, a Dynamic Surgical Guidance - DSG, called PediGuard $₫$ probe was developed.
This probe has the ability to identify different tissues by measuring electrical conductivity. ${ }^{2-4}$ This device produces a sound, in which changes in pitch and cadence indicates a change in tissues around the tip of PediGuard ${ }^{\circledR}$ probe. A mid-range pitch and cadence audio signal is produced as the probe is in the cancellous bone. A low cadence pitch and cadence audio signal is performed as the probe approaches the pedicle cortical wall and it is the first indication of a potential pedicle breach. ${ }^{3-5}$ The ability of Dynamic Surgical Guidance-DSG (PediGuard ®probe) to improve pedicle screw accuracy and to reduce radiation exposure has been shown in vitro using human cadaver specimens as well as in clinical trials. ${ }^{6}$

All authors declare no potential conflict of interest related to this article.

The study was conducted at Laboratório de Bioengenharia da Faculdade de Medicina de Ribeirão Preto da Universidade de São Paulo.

Correspondence: Rômulo Pedroza Pinheiro. Av. Bandeirantes 3900, Ribeirão Preto, SP, Brazil, 14049900. romulopinheiro@usp.br 
A further development of Dynamic Surgical Guidance technique was the combination of Dynamical Surgical Guidance technology and a pedicle screw in just one device to develop a "A Dynamic Surgical Guidance Screw" (DSG Screw). The DSG Screw is a pedicle screw system with a breach anticipation sensor located at the tip of the screw. The device provides a real-time surgical guidance and the ability to insert directly the screw into the pedicle without drilling a pilot hole neither tapping. ${ }^{7}$ The screw can be introduced directly into the pedicle and redirected during insertion according to the pitch and cadence of the audio signal. Besides, the DSG Screw insertion into the pedicle without drilling it do not require fluoroscopy for guidance, reducing intra-operative radiation and the operating time.

This study experimentally evaluate the pullout strength of DSG screw using the direct screw insertion technique. We tested the hypothesis that smart screw has higher pullout strength after its insertion directly in the block without pilot hole and tapping.

\section{MATERIALS AND METHODS}

One hundred and five polyurethane blocks of $8 \mathrm{~cm}$ height, $5 \mathrm{~cm}$ width and $5 \mathrm{~cm}$ length, with a density of 10 PCF $\left(0.16 \mathrm{~g} / \mathrm{cm}^{3}\right)$ (National Ltda.) were used as test bodies to introduce screws and to perform the mechanical pullout tests. SpineGuard/Zavation Dynamic Surgical Guidance Z-Direct Screw (DSG Screw of $5.5 \mathrm{~mm}$ and $6.5 \mathrm{~mm}$ outer diameter and $40 \mathrm{~mm}$ length) were inserted into the blocks according to the experimental group (Figure 1). The experimental groups were formed according to the use of pilot hole and tap diameter (undertapping and line to line). Thread taps $4.5 \mathrm{~mm}, 5.5 \mathrm{~mm}$ and $6.5 \mathrm{~mm}$ were used. The $4.5 \mathrm{~mm}$ tap was used as undertap for $5.5 \mathrm{~mm}$ screws. The $5.5 \mathrm{~mm}$ tap was used as undertap for $6.5 \mathrm{~mm}$. All taps have a $2.9 \mathrm{~mm}$ pitch and a double lead design.

The screws were inserted into the blocks according to the experimental group. Each experimental group was formed by ten polyurethane blocks. For the $5.5 \mathrm{~mm}$ screws there were four experimental groups, and the screws were inserted: 1 - directly into the polyurethane block (without previous pilot hole and tapping), 2 - with a $2 \mathrm{~mm}$ pilot hole without tapping, 3 - undertapping ( $2 \mathrm{~mm}$ pilot hole and $4.5 \mathrm{~mm}$ tap), 4 - line to line ( $2 \mathrm{~mm}$ pilot hole and 5.5 tap). For the $6.5 \mathrm{~mm}$ screws there were five experimental groups: 1 - directly into the polyurethane block (without previous pilot hole and tapping), 2 - with a $2 \mathrm{~mm}$ pilot hole without tapping, 3 - undertapping ( $2 \mathrm{~mm}$ pilot hole and $4.5 \mathrm{~mm}$ tap), 4 - undertapping ( $2 \mathrm{~mm}$ pilot hole and $5.5 \mathrm{~mm}$ tap), 5 - line to line ( $2 \mathrm{~mm}$ pilot hole and 6.5 tap).

After screw insertion, pullout strength was evaluated using universal test machine (EMIC-DL10000, São José dos Pinhais, PR, Brazil). A rod was attached to the head of the screw and pullout force was applied vertically. This force was applied at a speed of $2.0 \mathrm{~mm} / \mathrm{min}$ until the screw was pulled out of the polyurethane block.

\section{Statistical methods}

Continuous variables were expressed as the means and standard deviations (SD). The results from pullout forces were subjected to statistical analysis of normality using the Kolmogorov-Smirnov test, in order to determine the behavior of the data. The results obtained in the four groups were compared using three-way analysis of variance, followed by Tukey's post hoc test. Statistically significant differences were noted when $p<0.05$. Statistical analyses were determined using Prism v8.4.3 Graphs were generated using Prism v8.4.3 (GraphPad, San Diego, CA).

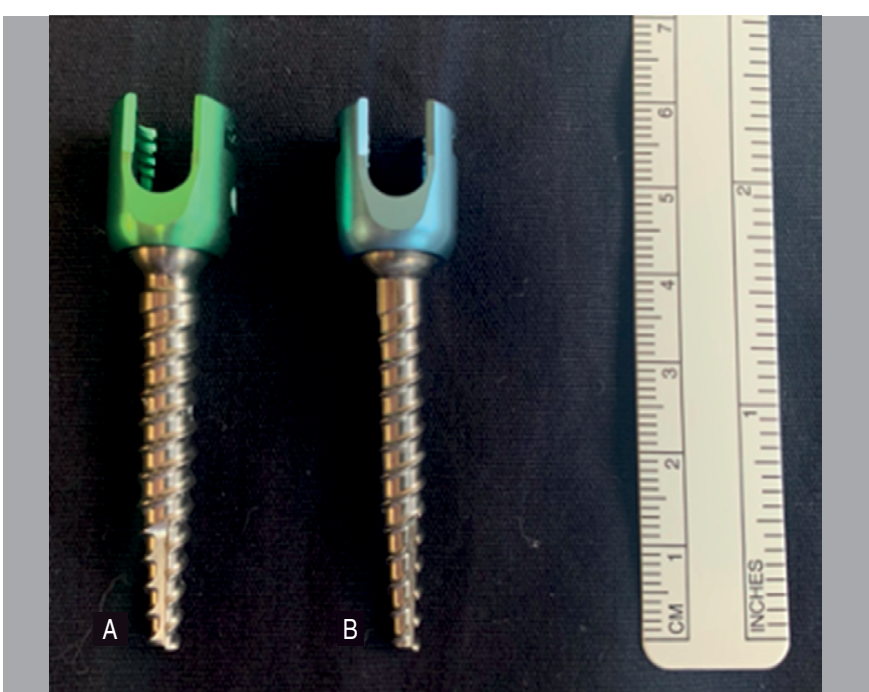

Figure 1. Photo of SpineGuard/Zavation Dynamic Surgical Guidance Z-Direct screw of and (A) $6.5 \mathrm{~mm}$ and (B) $5.5 \mathrm{~mm}$ outer diameter.

\section{RESULTS}

Pilot hole and tapping have been previously reported to influence the screw pullout strength. To evaluate the influence of pilot hole preparation and techniques, screws without pilot hole, without tapping, with undertapping and line to line tapping were inserted. The results of the $5.5 \mathrm{~mm}$ and $6.5 \mathrm{~mm}$ screws pullout strength according to the experimental groups are illustrated in the Figures 2 and 3.

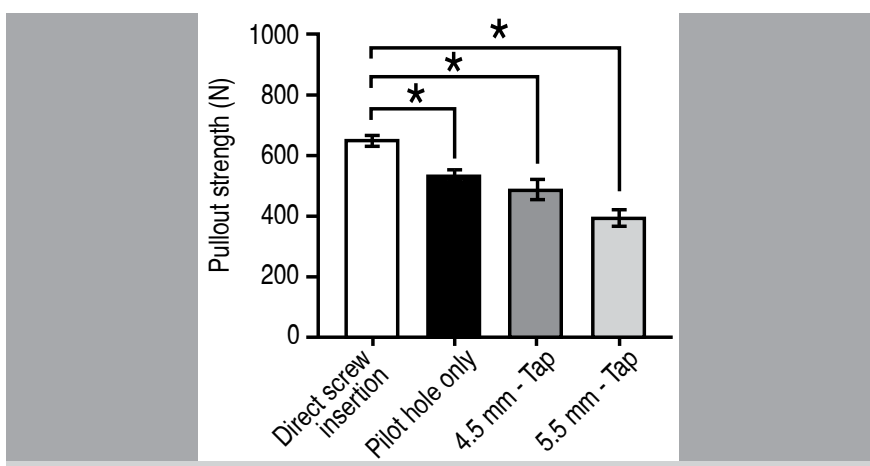

Figure 2. Mean maximal pullout strength of $5.5 \mathrm{~mm}$ SpineGuard / Zavation screw inserted into polyurethane blocks.

The asterisks $\left(^{\star}\right)$ indicate statistical difference.

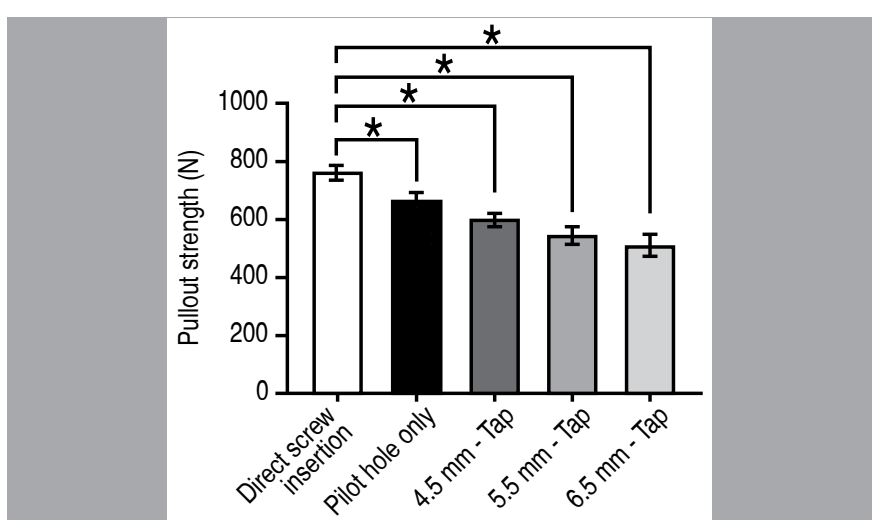

Figure 3. Mean maximal pullout strength of $6.5 \mathrm{~mm}$ SpineGuard/ Zavation screw inserted into polyurethane blocks.

The asterisks $\left(^{\star}\right)$ indicate statistical difference. 
The mean pullout strength for $5.5 \mathrm{~mm}$ and $6.5 \mathrm{~mm}$ screws inserted directly into the blocks without pilot hole or tapping were statistically higher, when compared to the other experimental groups $(p<0.05)$. As of note, we detected a $21 \%$ increase in the pullout strength of the $5.5 \mathrm{~mm}$ DSG screw during its direct insertion, when compared to the insertion with the use of pilot hole only. This increase was even higher when the direct insertion was compared to the other experimental groups; $33 \%$ increase versus $4.5 \mathrm{~mm}$ tapping and $65 \%$ versus $5.5 \mathrm{~mm}$ tapping (Figure 2). With regards to the $6.5 \mathrm{~mm} \mathrm{DSG}$ screw, we detected a $15 \%$ increase in the pullout strength during its direct insertion, when compared to the insertion with the use of pilot hole only; $27 \%$ increase versus $4.5 \mathrm{~mm}$ tapping; $40 \%$ versus $5.5 \mathrm{~mm}$ tapping; and 49\% versus $6.5 \mathrm{~mm}$ tapping (Figure 3). An increase of screw pullout strength was observed from the experimental groups using line to line tapping to the experimental group, in which the screws were inserted without pilot hole.

\section{DISCUSSION}

Our in vitro findings support the hypothesis that SpineGuard/ Zavation screw has higher pullout strength after its insertion and tapping directly into the block without pilot hole. Higher pullout strength of DSG screw was recorded after its direct insertion into the polyurethane blocks compared with insertion with pilot hole, undertapping or line-to-line tapping.

Since the initial report on the use of pedicle screw for spine fixation, there has been a permanent improvement of this modality of spinal fixation, that is widely used to treat fractures, degenerative disease, tumor, deformities and spinal stability. ${ }^{6-9}$ Pedicle screws continue to be studied to improve its locking mechanism in fixation system components, biomechanical screw performance and screw accuracy. ${ }^{10}$ The main biomechanical requirements of pedicle screw are resistance to cantilever loads (loads oriented perpendicular to the long axis of screw as bending strength) and pullout resistance.

The bending strength depends on the material and it is proportional to screw core diameter. ${ }^{11-12}$ The strength increases exponentially, it is proportional to the cube of screw core diameter, therefore the largest screw diameter allowed by the bony local anatomy should be used to minimized the likelihood of screw failure. ${ }^{13-18}$

Pullout resistance of the pedicle screw is influenced by bone mineral density, ${ }^{5}$ screw geometry and insertion technique employed by the surgeon. Changes in screw design and optimization of pilot hole has been explored to improve the anchorage of the pedicle screws, as modifications of bone mineral density are not possible to be made acutely. ${ }^{19}$ In bone with compromised BMD, augmentation of the screw with polymethylmethacrylate, calcium phosphate or hydroxyapatite, or modification to the screw diameter, length, thread design, expandable screws, fenestrated screw or change in screw trajectory has been attempted to increase the purchase of the implants. ${ }^{19}$

The usual and current surgical technique for pedicle screw insertion is a sequence of pilot hole followed by tapping and screw insertion..$^{19,20}$ The screw insertion is generally preceded by a pre-tapping using a smaller diameter than screw. ${ }^{7}$ If the screw is inserted in untapped pilot hole, rates of misalignment may increase. ${ }^{10}$ The holding power or pullout strength is influenced by the amount of bone inside the screw threads. ${ }^{16}$ The perforation and tapping of the pilot hole result in additional trauma, increase operative time and decrease the screw pullout strength. ${ }^{13}$ To eliminate these drawbacks, changes of screw designs were performed to eliminate drilling of the pilot hole and tapping. ${ }^{14}$ Self-drilling and self-tapping screws were developed and used in spinal surgery for cervical plate fixation, ${ }^{10}$ whose screw path is not so critical as pedicle screw. Pedicle screw should be inserted inside the pedicle wall that is surrounded by neural and other anatomical structures that can be injured. ${ }^{15,16}$ Pedicles screws are typically placed using pilot holes and the trajectory of the pilot holes can be verified by pedicle sounding. Although pilot holes and tapping do not ensure that the screw will follow the pilot hole trajectory, for tapped pilot holes the risk of screw malposition is lower. ${ }^{10}$

Pullout strength is proportional to the volume of bone inside the screw thread, ${ }^{13}$ bone implant-contact with increased area and density of bone inside and outside the screw thread is promoted by self-drilling screw as the DSG screw. However, screw pullout strength depends also on changes induced in bone by insertion trauma, reaction of bone to implant and resorption and remodeling as a result of healing. ${ }^{15}$ Silva et al. reported increased implant-bone contact in vivo after screws inserted in pilot holes smaller than the screw internal diameter. ${ }^{16}$ The highest pull-out strength of the direct screw insertion technique can be explained by a higher amount of bone squeezed at the bone-implant interface contact. Furthermore, in vivo studies may be required to confirm these findings.

The limitation of the study related to the used experimental model should be considered. Pullout strength test may not be commonly seen in a clinical setting, but its simplicity and reproducibility allow it to be considered as the most efficient method to compare screw anchorage within the bone. ${ }^{13,15,16}$ Axial pullout test is easy to perform, reproducible and is accepted as a good predictor of the mechanical performance of the screw. Yet, pedicles screws are subjected to a complex mechanically demanding situation represented by an association of twisting, bending and pullout force ${ }^{17,18}$. Most of the time, pedicle screws fail by cyclic loading rather one-time pullout. Screw pullout strength does not represent the only mechanism of screw failure, but it still reflects the magnitude of screw anchorage purchase. ${ }^{18}$

\section{Clinical applications}

The DSG screw combines the characteristics that have been desired for pedicle screws, combining great resistance to pullout and improved positioning accuracy. However, only after the use of DSG screw in clinical settings and evaluation of the outcomes, the true benefits of DSG screw could be confirmed. Preliminarily, the results of the initial experimental evaluation showed advantages of the DSG screw. This component and its direct screw insertion technique provides better pullout strength. In addition, The DSG screw is a time saving approach compared to the traditional pedicle screw placement because screw insertion can be performed without pilot hole and tapping. The accuracy of the screw positioning is not compromised as all along the insertion as the DSG technology is providing guidance in real time to ensure a safe trajectory within the pedicle. And finally, the DSG screw, guided by the bipolar sensor on the tip of the screw, could also reduce intraoperative radiation. Preliminary reports of clinical use of this component was shown to be very successful (although not published yet).

\section{CONCLUSION}

The DSG screw and its direct screw insertion technique shows higher pullout strength in experimental in vitro study and it also has the advantage to improve accuracy of pedicle screw insertion with less radiation exposure. The DSG screw has the potential to change the way pedicle screw is inserted, for a faster and more accurate technique with less radiation. However, only after clinical use and evaluation of its cost benefit, its real advantage will be considered.

AUTHORS' CONTRIBUTIONS: Each author contributed individually and significantly to the development of this article. RPP: data collection, writing of the article, data analysis, project review, intellectual concept and article review; AZ: data collection; TC: study design; KG: study design; ACS: data analysis and project review; HLAD: data collection, writing of the article, data analysis, project review, intellectual concept and article review. 


\section{REFERENCES}

1. Bolger C, Wigfield C. Image-guided surgery: applications to the cervical and thoracic spine and a review of the first 120 procedures. J Neurosurg. 2000;92(2 Suppl):175-80

2. Bolger C, Carozzo C, Roger T, McEvoy L, Nagaria J, Vanacker G, Bourlion M. A preliminary study of reliability of impedance measurement to detect iatrogenic initial pedicle perforation (in the porcine model). Eur Spine J. 2006;15(3):316-20.

3. Chen LH, Tai CL, Lai PL, Lee DM, Tsai TT, Fu TS, et al. Pullout strength for cannulated pedicle screws with bone cement augmentation in severely osteoporotic bone: influences of radial hole and pilot hole tapping. Clin Biomech (Bristol, Avon). 2009;24(8):613-8.

4. Bolger C, Kelleher MO, McEvoy L, Brayda-Bruno M, Kaelin A, Lazennec JY, e al. Electrical conductivity measurement: a new technique to detect iatrogenic initial pedicle perforation. Eur Spine J. 2007;16(11):1919-24.

5. Chen SH, Mo Lin R, Chen HH, Tsai KJ. Biomechanical effects of polyaxia pedicle screw fixation on the lumbosacral segments with an anterior interbody cage support. BMC Musculoskelet Disord. 2007;8:28.

6. Williams J, Samdani A, Defino HLA, George K, Gaughan J, Betz R. Anticipation of vertebral pedicle breach through dynamic surgical guidance. Coluna/Columna. 2014;13(3):210-3.

7. Bohl DD, Basques BA, Golinvaux NS, Toy JO, Matheis EA, Bucklen BS, Grauer JN. Undertapping of Lumbar Pedicle Screws Can Result in Tapping With a Pitch That Differs From That of the Screw, Which Decreases Screw Pullout Force. Spine (Phila Pa 1976). 2015;40(12):E729-34.

8. Ovadia D, Korn A, Fishkin M, Steinberg DM, Wientroub S, Ofiram E. The contribution of an electronic conductivity device to the safety of pedicle screw insertion in scoliosis surgery. Spine (Phila Pa 1976). 2011;36(20):E1314-21.

9. Benzel EC. Biomechanics of Spine Stabilization. New York: Thieme; 2001.
10. Carmouche JJ, Molinari RW, Gerlinger T, Devine J, Patience T. Effects of pilot hole preparation technique on pedicle screw fixation in different regions of the osteoporotic thoracic and lumbar spine. J Neurosurg Spine. 2005;3(5):364-70.

11. Defino HLA, Rosa RC, Silva P, Shimano AC, Volpon JB, Paula FJA, et al. The effect of repetitive pilot-hole use on the insertion torque and pullout strength of vertebral system screws. Spine (Phila Pa 1976). 2009;34(9):871-6.

12. Lill CA, Schneider E, Goldhahn J, Haslemann A, Zeifang F. Mechanical performance of cylindrical and dual core pedicle screws in calf and human vertebrae. Arch.Orthop Trauma Surg. 2006;126(10):686-94

13. Benzel EC. Implant-bone interfaces. In: Benzel EC. Biomechanics of Spinal Stabilization. New York: Thieme; 2001. p. 155-70.

14. Silva P, Rosa RC, Shimano AC, Paula FJA, Volpon JB, Defino HLA. Avaliação biomecânica da influência do macheamento e do desenho dos parafusos cervicais. Rev Bras Ortop. 2009;44(5):415-9.

15. Schatzker J, Sanderson R, Murnaghan JP. The holding power of orthopedic screws in vivo. Clin Orthop Relat Res. 1975;(108):115-26.

16. Silva $P$, Rosa RC, Shimano AC, Defino HLA. Effect of pilot hole on biomechanical and in vivo pedicle screw-bone interface. Eur Spine J. 2013;22(8):1829-36.

17. Erkan S, Hsu B, Wu C, Mehbod AA, Perl J, Transfeldt EE. Alignment of pedicle screws with pilot holes: can tapping improve screw trajectory in thoracic spines? Eur Spine J. 2010; 19(1):71-7.

18. Uhl RL. The biomechanics of screws. Orthop Rev. 1989;18(12):1302-7.

19. Shea TM, Laun J, Gonzalez-Blohm SA, Doulgeris JJ, Lee WE 3rd, Aghayev $\mathrm{K}$, Vrionis FD. Designs and techniques that improve the pullout strength of pedicle screws in osteoporotic vertebrae: current status. Biomed Res Int 2014;2014:748393

20. Defino HLA, Miranda RF, Pinheiro RP, Shimano AC. Influência do diâmetro e geometria no macheamento do orifício piloto nos parafusos pediculares. Coluna/Columna [online]. 2019;18(1):51-4. 